\title{
Alteration of Galectin-3 in Tears of Patients With Dry Eye Disease
}

\section{Citation}

Uchino, Yuichi, Jerome Mauris, Ashley M. Woodward, Julia Dieckow, Francisco Amparo, Reza Dana, Flavio Mantelli, and Pablo Argüeso. 2015. "Alteration of Galectin-3 in Tears of Patients With Dry Eye Disease." American Journal of Ophthalmology 159 (6) (June): 1027-1035.e3. doi:10.1016/j.ajo.2015.02.008.

\section{Published Version}

10.1016/j.ajo.2015.02.008

\section{Permanent link}

http://nrs.harvard.edu/urn-3:HUL.InstRepos:34854270

\section{Terms of Use}

This article was downloaded from Harvard University's DASH repository, and is made available under the terms and conditions applicable to Open Access Policy Articles, as set forth at http:// nrs.harvard.edu/urn-3:HUL.InstRepos:dash.current.terms-of-use\#OAP

\section{Share Your Story}

The Harvard community has made this article openly available.

Please share how this access benefits you. Submit a story.

\section{Accessibility}


Published in final edited form as:

Am J Ophthalmol. 2015 June ; 159(6): 1027-1035.e3. doi:10.1016/j.ajo.2015.02.008.

\title{
Alteration of Galectin-3 in Tears of Patients with Dry Eye Disease
}

\author{
Yuichi Uchino, Jerome Mauris, Ashley M. Woodward, Julia Dieckow, Francisco Amparo, \\ Reza Dana, Flavio Mantelli, and Pablo Argüeso \\ Schepens Eye Research Institute and Massachusetts Eye and Ear, Department of \\ Ophthalmology, Harvard Medical School, Boston, Massachusetts (Y.U., J.M., A.M.W., J.D., F.A., \\ R.D., P.A.); and the Campus Bio Medico University of Rome, Rome, Italy (F.M.)
}

\begin{abstract}
Purpose-To investigate the expression, release, and proteolytic degradation of galectin-3 in patients with dry eye disease.
\end{abstract}

Design-Observational case series with a comparison group.

Methods-Tear washes and conjunctival impression cytology specimens were collected through standard procedures from 16 patients with dry eye and 11 age-matched healthy subjects.

Galectin-3 content in tears was analyzed by quantitative Western blot, using recombinant galectin-3 protein to generate a calibration curve. The relative expression of galectin-3 and matrix metalloproteinase 9 (MMP9) was evaluated by quantitative polymerase chain reaction. The cleavage of galectin-3 was studied in vitro using activated recombinant MMP9 and protease inhibitors.

Results-The concentration of galectin- 3 protein in tears, but not galectin- 3 expression in conjunctival epithelium, was significantly higher in tears of patients with dry eye $(0.38 \mathrm{ng} / \mu \mathrm{g}$ total protein, range $0.04-1.36)$ compared to healthy subjects $(0.12 \mathrm{ng} / \mu \mathrm{g}$ total protein, range $0.00-0.41)$ $(\mathrm{P}<.01)$. By Western blot, an intact $(\sim 28.0 \mathrm{kDa})$ galectin-3 band was identified in tear samples

(C) 2015 Published by Elsevier Inc.

Inquiries to Pablo Argüeso, Ph.D., Schepens Eye Research Institute and Massachusetts Eye and Ear, Department of Ophthalmology, Harvard Medical School, 20 Staniford Street, Boston, MA 02114; pablo_argueso@ meei.harvard.edu Tel: 617-912-0249; Fax: 617-912-0101.

Supplemental Material available at AJO.com

Conflict of Interest: No conflicting relationship exists for any author.

Financial Disclosure(s): All authors have completed and submitted the ICMJE Form for Disclosure of Potential Conflicts of Interest, and the following were reported. Y.U. has received consulting fees from Santen and Otsuka, and lecture fees from Santen and Otsuka. R.D. is consultant to Alcon, Cambium, Eleven Biotherapeutics, Gurnet Point Capital, NovaBay, and Rigel. He holds equity at Eleven Biotherapeutics. F.M. is currently an employee of Dompé US. P.A. has received grant/research support from Alcon, Otsuka, and Santen, and has served in a consulting or advisory capacity for Fovea Pharmaceuticals, Otsuka, and Santen.

Contributions of Authors: Conception and design of study (Y.U., J.M., P.A.); Analysis and interpretation of data (Y.U., J.M., P.A.); Writing the article (Y.U., P.A.); Critical revision of the article (Y.U., J.M., A.M.W., J.D., F.A., R.D., F.M., P.A.); Final approval of the article (Y.U., J.M., A.M.W., J.D., F.A., R.D., F.M., P.A.); Data collection (Y.U., A.M.W., J.D., F.A., F.M.); Provision of materials, patients, or resources (R.D., F.M., P.A.); Statistical expertise (Y.U.); Obtaining funding (Y.U., R.D., P.A.); Literature search (Y.U., J.M., P.A.); Administrative, technical, or logistic support (Y.U., J.M., A.M.W., J.D., P.A.). Each author meets the 4 criteria set by the ICMJE required to claim authorship.

Publisher's Disclaimer: This is a PDF file of an unedited manuscript that has been accepted for publication. As a service to our customers we are providing this early version of the manuscript. The manuscript will undergo copyediting, typesetting, and review of the resulting proof before it is published in its final citable form. Please note that during the production process errors may be discovered which could affect the content, and all legal disclaimers that apply to the journal pertain. 
from healthy subjects, whereas $50 \%$ of the dry eye samples were characterized by the additional presence of a partially degraded form $(\sim 25.4 \mathrm{kDa})$. In our experiments, elevated expression of MMP9 in dry eye subjects correlated with the ability of active MMP9 to cleave galectin-3 from recombinant origin. Interestingly, cleavage of endogenous galectin-3 in tear samples was impaired using a broad-spectrum proteinase inhibitor cocktail, but not the pan-specific MMP inhibitor GM6001, suggesting the presence of proteases other than MMPs in promoting galectin-3 degradation in dry eye.

Conclusions-Our results indicate that release of cellular galectin-3 into tears is associated with epithelial dysfunction in dry eye, and that galectin-3 proteolytic cleavage may contribute to impaired ocular surface barrier function.

\section{Keywords}

galectin-3; tears; dry eye disease; ocular surface barrier function; proteolytic activity

\section{Introduction}

Disruption of epithelial barrier function is associated with a wide range of disorders that includes dry eye, a disease affecting millions of people worldwide and whose pharmacological treatment remains unsatisfactory. ${ }^{1}$ While the intercellular junctions that connect individual cell membranes on mucosal surfaces have been clearly defined as components of the paracellular barrier, ${ }^{2}$ research performed during the last decade has redefined and highlighted the contribution of apical cell membranes as an additional layer of protection-the transcellular or glycocalyx barrier. Indeed, both molecular and structural changes of the glycocalyx in apical cells within the stratified squamous epithelium have been observed in drying diseases, 3,4 and appear to correlate with loss of barrier function at the ocular surface. ${ }^{5,6}$

Transmembrane mucins (MUCs), such as MUCs 1, 4 and 16, are an essential component of the glycocalyx barrier in mucosal epithelia. ${ }^{7,8}$ They have single membrane-spanning regions with large extracellular glycosylated domains that form rod-like structures extending 200-500 nm above the plasma membrane, far above other glycoconjugates in the glycocalyx. ${ }^{9}$ Extensive research has shown that O-glycans, a form of glycosylation resulting from the addition of $\mathrm{N}$-acetylgalactosamine to serine or threonine residues in the mucin ectodomain, are critical to preventing epithelial damage and infection of mucosal surfaces. ${ }^{10,11}$ At the ocular surface, transmembrane mucins contribute to provide boundary lubrication and to prevent the penetrance of extracellular molecules and pathogenic microorganisms onto the epithelia. ${ }^{12}$

It is now clear that transmembrane mucins and their associated glycans promote the integrity of the epithelial barrier at the ocular surface by interacting on the apical glycocalyx with galectin-3. ${ }^{13}, 14$ Galectin-3 is a multivalent $\beta$-galactoside-binding lectin known to promote formation of plasma membrane lattices with unique functions, concentrating specific glycoproteins within the lattice while excluding other molecules. ${ }^{15}, 16$ Similarly to other members of the galectin family, galectin-3 is defined by the presence of an evolutionarily conserved carbohydrate-binding domain that mediates receptor binding. ${ }^{17}$ Critical to the 
multimerizing function of galectin-3 is the presence of an N-terminal domain that allows self-association through intermolecular interactions when bound to a multivalent ligand. ${ }^{18}$ Using site-directed mutagenesis, we have recently shown that maintenance of ocular surface glycocalyx integrity in vitro requires the N-terminal multimerization domain of galectin-3. ${ }^{14}$ To date, however, much remains unknown about the synthesis and structural integrity of galectin-3 in patients with altered ocular surface barrier function. In the present study, we investigated whether alteration of galectin-3 is associated with dry eye, by evaluating the expression and release of galectin- 3 onto the ocular surface, and examining whether galectin-3 undergoes proteolytic degradation in tears.

\section{Methods}

\section{Study population}

This observational case series study was conducted in compliance with good clinical practice, Institutional Review Board approval (Campus Bio Medico University of Rome, IRB \# 07/06.PARComEtCBM; Massachusetts Eye and Ear Infirmary, IRB \#12-1591-1), informed-consent regulations and the tenets of the Declaration of Helsinki. A total of sixteen patients (10 women, 6 men) with dry eye disease were recruited from Fondazione GB Bietti and Massachusetts Eye and Ear Infirmary, with a mean age of 56.9 \pm 11.0 years (range, 3584 years). Within this population, twelve patients were aqueous-deficient without meibomian gland disease (MGD), three were aqueous-deficient with MGD, and one was aqueous-sufficient with MGD (Supplementary Table). Within the MGD patients, one had Sjögren's syndrome and two had graft versus host disease (GVHD). None of the patients had chalasis. The subjects completed an IRB approved questionnaire regarding history of ocular allergies, disease, surgery, contact lens wear, current medications, type and frequency of symptoms of dry eye and dry mouth, and the use of dry eye therapy. Inclusion criteria were symptoms of dry eye and at least one of the following objective signs: Schirmer I $<10 \mathrm{~mm}$ at 5 minutes, decreased tear breakup time (TBUT) of $\mathbf{5}$ seconds, and positive vital dye staining of the conjunctiva or cornea. The degree of positive staining used for the diagnosis of dry eye corresponds to scores higher than 1 in the Oxford Scheme, or higher than 3 in the Bijsterveld score. Patients with a history of ocular surgery, topical anti-glaucoma or antiinflammatory therapy, or eye allergies were excluded. Eleven age- and sex-matched healthy subjects ( 7 women, 4 men) without dry eye symptoms, eye diseases, or history of eye surgery or contact lens wear were used as a control group. The mean age of the control group was $55.6 \pm 11.5$ years (range, $34-72$ years).

\section{Sample collection}

Tear fluid and conjunctival epithelium from healthy subjects and patients with dry eye disease were collected to determine galectin-3 protein levels, and galectin-3 and matrix metalloproteinase 9 (MMP9) messenger ribonucleic acid (mRNA) expression, respectively. Tear fluid was collected from unanesthetized eyes by pipetting $60 \mu \mathrm{L}$ sterile saline (AddiPak ${ }^{\circledR} 0.90 \%$ sodium chloride sterile solution) into the inferior fornix using a sterile transfer pipet, followed by movement of the eyes to mix the tear fluid content as described. ${ }^{19}$ The volumes acquired ranged between 14.0 and $72.6 \mu \mathrm{L}$ (average $42.9 \mu \mathrm{L}$ ). Then, a drop of topical anesthetic (proparacaine hydrochloride, 0.5\%, Alcaine ${ }^{\circledR}$; Alcon Inc.; 
Ft. Worth, TX) was applied to the eye. A sterile disc of nitrocellulose filter paper, $10 \mathrm{~mm}$ in diameter, was placed on the temporal bulbar conjunctiva, gentle pressure was applied to the disc for 15 seconds, and the disc was then carefully transferred into an Eppendorf tube containing TRIzol reagent (Gibco; Grand Island, NY). All samples were promptly frozen at $-80^{\circ} \mathrm{C}$ until the time of analyses.

Individual tear samples were centrifuged for 30 minutes at $18,000 \times \mathrm{g}$ at $4^{\circ} \mathrm{C}$ using a microcentrifuge (centrifuge 5424R, Eppendorf, Hamburg, Germany). Protein concentration was determined using the Micro bicinchoninic acid (BCA) Protein Assay Kit (Thermo Scientific, Waltham, MA), according to the manufacturer's protocol.

\section{Production of Recombinant Human Galectin-3}

Recombinant human galectin-3 (rhGal-3) was expressed as previously reported. ${ }^{14}$ Briefly, heterologous protein expression was induced by addition of $0.3 \mathrm{mM}$ of isopropyl $\beta$-D-1thiogalactopyranoside (IPTG) to Rosetta $E$. coli clones carrying a rGal-3 vector, followed by incubation overnight at $15^{\circ} \mathrm{C}$ with shaking. The rhGal-3 was purified from lysates by affinity chromatography using lactosyl sepharose. To eliminate contaminating bacterial endotoxins, rGal-3 was further purified by polymyxinB affinity chromatography. The absence of lipopolysaccharide was confirmed using ToxinSensor ${ }^{\mathrm{TM}}$ Chromogenic LAL Endotoxin Assay Kit (GenSript, Piscataway, NJ, USA). Protein solutions were concentrated by filtration (VIVASPIN, Littleton, MA, USA), dialyzed against phosphate-buffered saline (PBS) buffer containing $10 \%$ glycerol and stored at $-20^{\circ} \mathrm{C}$. Protein concentration was determined using the BCA Protein Assay Kit (Thermo Scientific).

\section{Immunoblotting}

Tear samples containing 1-10 $\mu \mathrm{g}$ of total protein were separated by electrophoresis on $10 \%$ sodium dodecyl sulfate-polyacrylamide gel electrophoresis (SDS-PAGE) gels and transferred onto nitrocellulose membranes (BioRad Laboratories). Membranes were then blocked with 5\% nonfat dry milk in Tris buffered saline with Tween (TBST) for 2 hours at room temperature, followed by incubation overnight at $4{ }^{\circ} \mathrm{C}$ with the following primary antibodies diluted in 5\% nonfat dry milk in TBST: anti-galectin-3 (H160; 1:2-3,000; Santa Cruz Biotechnology; Dallas, TX), anti-MMP9 (ab38898; 1:2,000; Abeam; Cambridge, MA). Following incubation with the corresponding peroxidase-conjugated secondary antibody (1:2,000; Santa Cruz), positive binding was visualized using the SuperSignal West Pico Chemiluminescent Substrate (Thermo Scientific) on HyBlot CL autoradiography film (Denville Scientific; Inc., Metuchen, NJ). When no band intensity was detected using the West Pico substrate, membranes were subsequently incubated with an enhanced and more sensitive substrate (SuperSignal West Femto Maximum Sensitivity Substrate; Thermo Scientific), which enables detection of low femtogram amounts of protein. Band intensities were quantified by densitometry (ImageJ software; National Institutes of Health; Bethesda, MD; in the public domain available at http://rsb.info.nih.gov/nihimage).

Quantification of protein concentrations in tear fluid by immunoblotting was performed as previously described. ${ }^{20}$ Galectin-3 content (ng/ $\mathrm{gg}$ total protein) in tears was determined 
using a standard curve based on signal intensity generated with different concentrations of rhGal-3, and two internal controls of rhGal-3 per gel when analyzing experimental samples.

\section{RNA Isolation, cDNA Synthesis and Quantitative Polymerase Chain Reaction}

Total RNA was extracted from conjunctival impression cytology specimens using an extraction reagent (TRIzol; Life Technologies) according to the manufacturer's protocol. The integrity and concentration of the total RNA were determined using a NanoDrop 2000 Spectrophotometer (Thermo Scientific). One microgram of total RNA was treated with amplification-grade DNase I (Life Technologies) to eliminate residual genomic DNA and reverse transcribed into cDNA using random hexamer primers and reverse transcriptase (iScript; Bio-Rad; Hercules, CA) according to the manufacturer's protocol.

Detection of gene expression in conjunctival impression cytology specimens was performed by quantitative polymerase chain reaction (qPCR) using PrimePCR ${ }^{\mathrm{TM}}$ primers for galectin-3 (Unique Assay ID: qHsaCID0008552) and MMP9 (Unique Assay ID: qHsaCID0011597). The qPCR reactions were carried out in triplicates in a $20 \mu \mathrm{L}$ reaction volume using $1 \mu \mathrm{L}$ of cDNA, $1 \mu \mathrm{L}$ primers and the SYBR $®$ Fast master mix (KARA Biosystems; Wilmington, MA) in a Mastercycler® ep realplex ${ }^{2}$ thermal cycler (Eppendorf; Hauppauge, NY). The following parameters were used: 2 minutes at $95^{\circ} \mathrm{C}$, followed by 40 cycles of 5 seconds at $95^{\circ} \mathrm{C}$ and 30 seconds at $60^{\circ} \mathrm{C}$. All samples were normalized using glyceraldehyde-3phosphate dehydrogenase (GAPDH) housekeeping gene expression (PrimePCR ${ }^{\mathrm{TM}}$ GAPDH primers; Bio-Rad). The comparative $\mathrm{C}_{\mathrm{T}}$ method was used for relative quantitation of the number of galectin-3 and MMP9 transcripts, selecting the relative mRNA levels in samples from healthy subjects as the calibrator.

\section{Protease Cleavage Assays}

For recombinant galectin-3 protease cleavage assay, $10 \mathrm{ng}$ of rhGal-3 were incubated with increasing concentrations of activated recombinant human MMP9 (rhMMP9, Calbiochem, San Diego, CA) in Dulbecco's phosphate-buffered saline supplemented with magnesium and calcium (Thermo Scientific, Waltham, MA) at $37{ }^{\circ} \mathrm{C}$ for various time periods as indicated. Reactions were stopped by the addition of Laemmli buffer and then subjected to boiling for 5 minutes. For endogenous galectin-3 protease cleavage assay, tear samples (3-5 $\mu \mathrm{g}$ total protein) from three patients with dry eye disease were incubated in PBS buffer at $37^{\circ} \mathrm{C}$ for 6 hours. In additional experiments, samples were supplemented with the pan-specific MMP inhibitor GM6001 ( $2 \mu \mathrm{M}$ for rhGal-3; $40 \mu \mathrm{M}$ for human tears) or a broad-spectrum proteinase inhibitor cocktail (complete ${ }^{\mathrm{TM}}$ EDTA free; Roche Applied Science; Mannheim, Germany). The reaction products were analyzed by electrophoresis on 10\% SDS-PAGE gels and visualized by immunoblotting.

\section{Statistical Analyses}

Statistical significance between normal and dry eye groups was evaluated with the MannWhitney $U$ test for nonparametric data, using a p value of 0.05 as the threshold for significance. Correlations between TBUT and galectin-3 protein concentration or gene expression were determined using the Spearman rank correlation test. All statistical analyses were performed using lnStat3 software (GraphPad Software, La Jolla, CA). 


\section{Results}

\section{Galectin-3 Levels Increase in Tears of Dry Eye Patients}

Altered levels of galectin-3 in biological fluids and sera have been associated with the pathophysiology of a number of diseases, such as asthma, heart failure, and cancer. ${ }^{21-23}$ To study a potential role of galectin-3 in dry eye disease, we developed a defined immunoblot method to quantify the levels of endogenous galectin-3 in human tear samples. For this purpose, a standard curve from a two-fold serial dilution series of rhGal-3 was produced to determine the linear range of detection for the galectin-3 antibody. Densitometric analysis of the protein bands revealed linear responses between 0.6 and $18 \mathrm{ng}$ of rhGal-3 (Figure 1, upper left). Next, we obtained the relative intensities of endogenous galectin-3 in human tears, normalized to the amount of total protein as previously described. ${ }^{24} \mathrm{We}$ found a significant increase in galectin-3 levels in tears of dry eye patients. As shown in Figure 1 (upper right) and Supplementary Table, the mean concentration of galectin-3 in control eyes was $0.12 \pm 0.04 \mathrm{ng} / \mu \mathrm{g}$ total protein (range $0.00-0.41$ ), whereas in dry eye it was $0.38 \pm 0.08$ $\mathrm{ng} / \mu \mathrm{g}$ total protein (range $0.04-1.36)(\mathrm{P}<.01)$.

To determine whether enhanced expression of galectin-3 mRNA at the ocular surface was responsible for the increase of galectin-3 protein in tears, we performed qPCR on samples of human conjunctival epithelium obtained by impression cytology from the same population groups. Interestingly, no significant differences in expression were observed between the healthy and dry eye groups (Figure 1, lower left). These results were consistent with data from a public database of microarray gene expression (http://www.functionalglycomics.org), showing no statistical differences in signal intensity for galectin-3 in conjunctiva of normal subjects and patients with dry eye disease (Figure 1, lower right).

\section{Galectin-3 Release into Tears Correlates with Tear Film Instability}

A key step in dry eye disease is the occurrence of an unstable tear film that eventually breaks up when in contact with an altered ocular surface epithelium. ${ }^{25}$ To determine a potential association between the amount of galectin-3 in tears and the occurrence of an unstable tear film, we performed a Spearman rank correlation test. As shown in Figure 2 (upper panel), we found a significant correlation between galectin-3 protein concentration in tears and tear instability as measured by tear film breakup time $(\mathrm{R}=-0.4988 ; \mathrm{P}<.01)$. In contrast, there was no correlation between galectin-3 gene expression in human conjunctival epithelium and tear film breakup time (Figure 2, lower panel).

\section{Galectin-3 is Partially Degraded in Tears of Dry Eye Patients}

Proteolytic degradation of galectin-3 is thought to impair the ability of the molecule to multimerize in the presence of binding partners, and to abrogate biological functions that depend on the ability of the lectin to form lattices. ${ }^{26}$ The human gelatinases MMP2 and MMP9 have been shown to induce cleavage of galectin-3 at the $\mathrm{Ala}_{62}-\mathrm{Tyr}_{63}$ bond in the Nterminus, resulting in a $22 \mathrm{kDa}$ cleavage product lacking the multimerization domain known as galectin-3C (Figure 3, upper panel). ${ }^{27}$ In our experiments, analysis of galectin-3 in human tears samples by immunoblot revealed the presence of a major galectin- 3 band with a molecular weight of $28.0 \mathrm{kDa}$ (Figure 3, lower left). Interestingly, we also detected the 
presence of a partially degraded form with a molecular weight of $25.4 \mathrm{kDa}$. Quantification of the ratio between galectin-3C and galectin-3 revealed a significant increase in tears of dry eye patients compared to tears of healthy subjects (Figure 3, lower right; Supplementary Table). Further, whereas higher values of galectin-3 were not associated with a particular etiology, the ratio between galectin-3C and galectin-3 in tears of patients with Sjögren's syndrome and GVHD was significantly higher than in other patients (data not shown).

\section{Degradation of Galectin-3 in Human Tears Involves Protease Activity}

Previous studies have shown that MMP9 activity is significantly higher in patients with dry eye disease. ${ }^{28,29}$ Therefore, to further explore the mechanism by which galectin- 3 is degraded in human tears, we analyzed the levels of MMP9 expression in conjunctival impression cytology samples collected from our study population. Consistent with previous data, we found a significantly higher expression of MMP9 mRNA in samples from dry eye patients compared to normal subjects (Figure 4, upper panel). In subsequent experiments, we tested whether active human rhMMP9 would cleave rhGal-3. Our results showed that active MMP9 promotes galectin-3 cleavage in a concentration- and time-dependent manner, producing a $25-\mathrm{kDa}$ cleavage product (Figure 4, middle and lower panels). As expected, the pan-specific MMP inhibitor GM6001 attenuated the degradation of full-length galectin-3 in control experiments.

Based on data using recombinant protein, we next hypothesized that cleavage of endogenous galectin-3 at the ocular surface would depend on the activity of MMP9 in human tears. To test this possibility, we developed an in vitro galectin-3 degradation assay with human tears (Figure 5). In this assay, tear samples were incubated at $37{ }^{\circ} \mathrm{C}$ for 6 hours to promote degradation of endogenous galectin-3. Analyses of tear samples from three dry eye patients revealed that, under these conditions, endogenous full-length galectin-3 was partially or completely degraded. Moreover, we also observed the appearance of galectin-3C in two of the three samples following incubation at $37{ }^{\circ} \mathrm{C}$ for 6 hours. Unexpectedly, we found that GM6001 could not prevent the proteolytic degradation of endogenous galectin-3 in human tears, in contrast to in vitro data using rhMMP9 and rhGal-3 (Figure 4, middle and lower panels). However, cleavage of endogenous galectin-3 could be partially prevented in samples from two patients by using the broad-spectrum proteinase inhibitor cocktail cOmplete ${ }^{\mathrm{TM}}$, suggesting the presence of proteases other than MMPs in promoting galectin-3 degradation at the ocular surface.

\section{Discussion}

The traditional model of mucosal protection portrays transmembrane mucins as passive molecules on the surface of epithelial cells. They emanate from apical plasma membranes, well above other glycoproteins, acting primarily as a physical barrier that prevents the influx of toxic agents and pathogens. It is now clear that transmembrane mucins contribute via glycosidic residues in an active manner to promote barrier function through interactions with galectin-3 on the ocular surface epithelial glycocalyx. ${ }^{13}, 14$ Here, we report that release of cellular galectin-3 into tears is associated with epithelial dysfunction in patients with dry eye. 
Galectin-3 is a carbohydrate-binding protein expressed in multiple epithelial tissues where it controls biological processes such as cell-cell and cell-extracellular matrix adhesion, cell growth and differentiation, cell-cycle, signaling, and apoptosis. ${ }^{17}$ Alteration in galectin-3 expression has been predominantly studied in cancer and inflammatory disease, but is commonly observed in many other pathological states. ${ }^{17,22}$ At the ocular surface,

Hrdlickova-Cela et al. used non-quantitative immunoblotting to report that galectin-3 was absent in tear fluid from four normal subjects, but present in tears of a limited cohort (mostly one subject per condition) of patients with diverse ocular surface disorders including bullous keratopathy, alkali burn, chronic blepharitis and adenoviral conjunctivitis. ${ }^{30}$ Our data showing increased levels of galectin-3 in tears of patients with dry eye disease are consistent with these findings reporting galectin-3 immunoreactivity in tears of patients with ocular surface disease. However, contrary to the results of Hrdlickova-Cela et al., we could also detect the presence of galectin-3 in normal tears, which could be explained by the analysis of a larger pool of subjects in our study population, and the use of a more sensitive detection assay for galectin-3. In our analyses, the severity of the disease did not correlate with the amount of galectin-3 or the cleavage of galectin-3 in tears (data not shown). It is possible to speculate that activation of compensatory mechanisms, such as increased glycosylation, in severe dry eye could lead to partial retention of galectin-3 on cell surfaces. Increased expression of glycosyltransferases has been observed before ocular surface keratinization in patients with ocular cicatricial pemphigoid. ${ }^{31}$ Further, the protease responsible for galectin-3 degradation in tears has yet to be identified, and its activity correlated with the severity of disease.

Interestingly, we found that the increase in galectin-3 levels in tear samples of dry eye patients did not correlate with an altered expression of galectin-3 mRNA in conjunctival impression cytology samples. We hypothesize that the discrepancy between galectin-3 protein and mRNA levels at the ocular surface could be explained by the disruption of the epithelial glycocalyx in dry eye disease. Mucins, like many other glycoproteins on cell surfaces, are subject to changes in glycosylation during pathological conditions that include inflammation. ${ }^{32}$ Further, it has been established that mucin glycosylation is altered in dry eye disease. ${ }^{33}$ Therefore, alterations on transmembrane mucin glycosylation in corneal and conjunctival epithelia could lead to loss of galectin-3 binding affinity and release of cellular galectin-3 into the tear film. It is also possible to speculate that galectin-3 in serum could diffuse into tears as a consequence of increased vascular and conjunctival epithelial permeability in dry eye, and that other cell types, such as those of the lacrimal gland or inflammatory cells present within the epithelium or tear fluid, could likewise contribute to secrete galectin-3 in these patients. In our assays, the tear fluid was subjected to low rate centrifugation to reduce the possibility of cellular contamination. ${ }^{30}$ However, it will be exciting to determine in future studies the individual contribution of increased permeability and the role of different cell types to the content of galectin- 3 at the ocular surface in dry eye.

Multimerization is a common feature of extracellular galectin-3 that leads to ligand crosslinking and the formation of lattice-like structures on cell surfaces ${ }^{34}$ Evidence suggests that degradation of galectin-3 results in the formation of a dominant-negative inhibitor, galectin-3C, that lacks the ability to multimerize and competes with extracellular full-length 
galectin- $3 .{ }^{35}$ Truncated forms of galectin- 3 have been detected in pathological conditions and have been shown to inhibit a variety of processes such as tumor growth and wound healing. ${ }^{36,37}$ Importantly, galectin-3C has a much higher binding affinity for the receptors compared to the full-length protein. ${ }^{38}$ In our experiments, we found that the ratio of galectin-3C to galectin-3 increased in tears of patients with dry eye. Although we do not know the biological consequences of an increased level of galectin-3C in dry eye disease, we speculate that it might play an important role in the impairment of ocular surface glycocalyx barrier function by interfering with the formation of transmembrane mucin lattices on apical cells within the stratified squamous epithelium. This hypothesis is supported by in vitro data indicating that treatment with a dominant-negative inhibitor of galectin-3 polymerization lacking the N-terminal domain, but not full-length galectin-3, prevented the recovery of barrier function in stratified human corneal epithelial cells. ${ }^{14}$

Previous reports have shown that the collagen-like domain of galectin-3 is susceptible to rapid and efficient cleavage by MMP2 and MMP9. ${ }^{27,} 39$ Consistent with previous data, ${ }^{28,}, 29$ we found a significantly higher expression of MMP9 mRNA in samples from dry eye patients that correlated with the ability of active MMP9 to cleave galectin-3 from recombinant origin in a dose- and time-dependent manner. Interestingly, we also found that cleavage of endogenous galectin-3 in tear samples could be impaired by using a broadspectrum proteinase inhibitor cocktail, but not the pan-specific MMP inhibitor GM6001, suggesting the presence of proteases other than MMPs in promoting galectin-3 degradation in tears of patients with dry eye. As with human tears, gelatinolytic activity and MMP9 immunoreactivity have been identified in human seminal plasma, however, endogenous metalloproteases purified from seminal plasma have failed to cleave galectin- $3 .^{40} \mathrm{It}$ is now clear that other proteases, such as prostate specific antigen, MMP13, neutrophil elastase, and leishmanolysin, can also degrade galectin-3. ${ }^{40-43}$ Exploring whether these or other candidates are responsible for the proteolytic degradation of galectin-3 at the ocular surface could bring novel insights into the mechanisms of epithelial dysfunction in dry eye disease. Further, data from these studies indicate that galectin- 3 could potentially be used as a biomarker for the evaluation and management of patients with ocular surface pathology. Assays to measure galectin-3 are available and have been found to aid in the prognosis of human disease.

\section{Supplementary Material}

Refer to Web version on PubMed Central for supplementary material.

\section{Acknowledgments}

Funding/Support: This study was supported by the National Eye Institute, National Institutes of Health, Bethesda, Maryland (grant no.: NEI014847 [P.A.]), the Japan Eye Bank Association (Y.U.), a postdoctoral fellowship from the Uehara Memorial Foundation in Japan (Y.U.) and Harvard Medical School Cornea Center of Excellence (R.D.).

Other Acknowledgments: None 


\section{References}

1. Lemp MA. Advances in understanding and managing dry eye disease. Am J Ophthalmol. 2008; 146(3):350-356. [PubMed: 18599017]

2. Madara JL. Warner-Lambert/Parke-Davis Award lecture. Pathobiology of the intestinal epithelial barrier. Am J Pathol. 1990; 137(6):1273-81. [PubMed: 2260620]

3. Koufakis DI, Karabatsas CH, Sakkas LI, Alvanou A, Manthos AK, Chatzoulis DZ. Conjunctival surface changes in patients with Sjogren's syndrome: a transmission electron microscopy study. Invest Ophthalmol Vis Sci. 2006; 47(2):541-4. [PubMed: 16431948]

4. Mantelli F, Mauris J, Argueso P. The ocular surface epithelial barrier and other mechanisms of mucosal protection: from allergy to infectious diseases. Curr Opin Allergy Clin Immunol. 2013; 13(5):563-8. [PubMed: 23974687]

5. Danjo Y, Watanabe H, Tisdale AS, et al. Alteration of mucin in human conjunctival epithelia in dry eye. Invest Ophthalmol Vis Sci. 1998; 39(13):2602-9. [PubMed: 9856770]

6. Pflugfelder SC, Tseng SCG, Yoshino K, Monroy D, Felix C, Reis BL. Correlation of Goblet Cell Density and Mucosal Epithelial Membrane Mucin Expression with Rose Bengal Staining in Patients with Ocular Irritation. Ophthalmology. 1997; 104(2):223-235. [PubMed: 9052626]

7. McAuley JL, Linden SK, Png CW, et al. MUC1 cell surface mucin is a critical element of the mucosal barrier to infection. J Clin Invest. 2007; 117(8):2313-24. [PubMed: 17641781]

8. Stonebraker JR, Wagner D, Lefensty RW, et al. Glycocalyx restricts adenoviral vector access to apical receptors expressed on respiratory epithelium in vitro and in vivo: role for tethered mucins as barriers to lumenal infection. J Virol. 2004; 78(24):13755-68. [PubMed: 15564484]

9. Hattrup CL, Gendler SJ. Structure and function of the cell surface (tethered) mucins. Annu Rev Physiol. 2008; 70:431-57. [PubMed: 17850209]

10. Fu J, Wei B, Wen T, et al. Loss of intestinal core 1-derived O-glycans causes spontaneous colitis in mice. J Clin Invest. 2011; 121(4):1657-66. [PubMed: 21383503]

11. Hanisch FG. O-glycosylation of the mucin type. Biol Chem. 2001; 382(2):143-9. [PubMed: 11308013]

12. Mantelli F, Argueso P. Functions of ocular surface mucins in health and disease. Curr Opin Allergy Clin Immunol. 2008; 8(5):477-83. [PubMed: 18769205]

13. Argueso P, Guzman-Aranguez A, Mantelli F, Cao Z, Ricciuto J, Panjwani N. Association of cell surface mucins with galectin-3 contributes to the ocular surface epithelial barrier. J Biol Chem. 2009; 284(34):23037-45. [PubMed: 19556244]

14. Mauris J, Mantelli F, Woodward AM, et al. Modulation of ocular surface glycocalyx barrier function by a galectin-3 N-terminal deletion mutant and membrane-anchored synthetic glycopolymers. PLoS One. 2013; 8(8):e72304. [PubMed: 23977277]

15. Brewer CF, Miceli MC, Baum LG. Clusters, bundles, arrays and lattices: novel mechanisms for lectin-saccharide-mediated cellular interactions. Curr Opin Struct Biol. 2002; 12(5):616-23. [PubMed: 12464313]

16. Rabinovich GA, Toscano MA, Jackson SS, Vasta GR. Functions of cell surface galectinglycoprotein lattices. Curr Opin Struct Biol. 2007; 17(5):513-20. [PubMed: 17950594]

17. Dumic J, Dabelic S, Flogel M. Galectin-3: an open-ended story. Biochim Biophys Acta. 2006; 1760(4):616-35. [PubMed: 16478649]

18. Ahmad N, Gabius HJ, Andre S, et al. Galectin-3 precipitates as a pentamer with synthetic multivalent carbohydrates and forms heterogeneous cross-linked complexes. J Biol Chem. 2004; 279(12):10841-7. [PubMed: 14672941]

19. Argueso P, Gipson IK. Assessing mucin expression and function in human ocular surface epithelia in vivo and in vitro. Methods Mol Biol. 2012; 842:313-25. [PubMed: 22259145]

20. Ferrero DM, Moeller LM, Osakada T, et al. A juvenile mouse pheromone inhibits sexual behaviour through the vomeronasal system. Nature. 2013; 502:368-71. [PubMed: 24089208]

21. McCullough PA, Olobatoke A, Vanhecke TE. Galectin-3: a novel blood test for the evaluation and management of patients with heart failure. Rev Cardiovasc Med. 2011; 12(4):200-10. [PubMed: 22249510] 
22. Gao P, Simpson JL, Zhang J, Gibson PG. Galectin-3: its role in asthma and potential as an antiinflammatory target. Respir Res. 2013; 14(1):136. [PubMed: 24313993]

23. Iurisci I, Tinari N, Natoli C, Angelucci D, Cianchetti E, Iacobelli S. Concentrations of galectin-3 in the sera of normal controls and cancer patients. Clin Cancer Res. 2000; 6(4):1389-93. [PubMed: 10778968]

24. Argueso P, Balaram M, Spurr-Michaud S, Keutmann HT, Dana MR, Gipson IK. Decreased levels of the goblet cell mucin MUC5AC in tears of patients with Sjogren syndrome. Invest Ophthalmol Vis Sci. 2002; 43(4):1004-11. [PubMed: 11923240]

25. Sharma A, Ruckenstein E. Mechanism of tear film rupture and its implications for contact lens tolerance. Am J Optom Physiol Opt. 1985; 62(4):246-53. [PubMed: 3993732]

26. Ochieng J, Green B, Evans S, James O, Warfield P. Modulation of the biological functions of galectin-3 by matrix metalloproteinases. Biochim Biophys Acta. 1998; 1379(1):97-106. [PubMed: 9468337]

27. Ochieng J, Fridman R, Nangia-Makker P, et al. Galectin-3 is a novel substrate for human matrix metalloproteinases-2 and -9. Biochemistry. 1994; 33(47):14109-14. [PubMed: 7947821]

28. Chotikavanich S, de Paiva CS, Li de Q, et al. Production and activity of matrix metalloproteinase-9 on the ocular surface increase in dysfunctional tear syndrome. Invest Ophthalmol Vis Sci. 2009; 50(7):3203-9. [PubMed: 19255163]

29. Sambursky R, Davitt WF 3rd, Latkany R, et al. Sensitivity and specificity of a point-of-care matrix metalloproteinase 9 immunoassay for diagnosing inflammation related to dry eye. JAMA Ophthalmol. 2013; 131(1):24-8. [PubMed: 23307206]

30. Hrdlickova-Cela E, Plzak J, Smetana K Jr, et al. Detection of galectin-3 in tear fluid at disease states and immunohistochemical and lectin histochemical analysis in human corneal and conjunctival epithelium. Br J Ophthalmol. 2001; 85(11):1336-40. [PubMed: 11673302]

31. Argueso P, Tisdale A, Mandel U, Letko E, Foster CS, Gipson IK. The cell-layer- and cell-typespecific distribution of GalNAc-transferases in the ocular surface epithelia is altered during keratinization. Invest Ophthalmol Vis Sci. 2003; 44(1):86-92. [PubMed: 12506059]

32. Corfield AP. Mucins: a biologically relevant glycan barrier in mucosal protection. Biochim Biophys Acta. 2015; 1850(1):236-52. [PubMed: 24821013]

33. Guzman-Aranguez A, Argueso P. Structure and biological roles of mucin-type O-glycans at the ocular surface. Ocul Surf. 2010; 8(1):8-17. [PubMed: 20105403]

34. Newlaczyl AU, Yu LG. Galectin-3--a jack-of-all-trades in cancer. Cancer Lett. 2011; 313(2):1238. [PubMed: 21974805]

35. Byrd, JC.; Mazurek, N.; Bresalier, RS. Post-translational modification of galectin-3 and its role in biological function. In: Klyosov, AA.; Traber, PG., editors. Galectins and disease implications for targeted therapeutics. Vol. xiv. Washington DC: American Chemical Society; 2012. p. 443

36. John CM, Leffler H, Kahl-Knutsson B, Svensson I, Jarvis GA. Truncated galectin-3 inhibits tumor growth and metastasis in orthotopic nude mouse model of human breast cancer. Clin Cancer Res. 2003; 9(6):2374-83. [PubMed: 12796408]

37. Puthenedam M, Wu F, Shetye A, Michaels A, Rhee KJ, Kwon JH. Matrilysin-1 (MMP7) cleaves galectin-3 and inhibits wound healing in intestinal epithelial cells. Inflamm Bowel Dis. 2011; 17(1):260-7. [PubMed: 20812334]

38. Shekhar MP, Nangia-Makker P, Tait L, Miller F, Raz A. Alterations in galectin-3 expression and distribution correlate with breast cancer progression: functional analysis of galectin-3 in breast epithelial-endothelial interactions. Am J Pathol. 2004; 165(6):1931-41. [PubMed: 15579437]

39. Nangia-Makker P, Raz T, Tait L, Hogan V, Fridman R, Raz A. Galectin-3 cleavage: a novel surrogate marker for matrix metalloproteinase activity in growing breast cancers. Cancer Res. 2007; 67(24):11760-8. [PubMed: 18089806]

40. Saraswati S, Block AS, Davidson MK, Rank RG, Mahadevan M, Diekman AB. Galectin-3 is a substrate for prostate specific antigen (PSA) in human seminal plasma. Prostate. 2011; 71(2):197208. [PubMed: 20672323]

41. Guevremont M, Martel-Pelletier J, Boileau C, et al. Galectin-3 surface expression on human adult chondrocytes: a potential substrate for collagenase-3. Ann Rheum Dis. 2004; 63(6):636-43. [PubMed: 15140769] 
42. Pelletier I, Sato S. Specific recognition and cleavage of galectin-3 by Leishmania major through species-specific polygalactose epitope. J Biol Chem. 2002; 277(20):17663-70. [PubMed: 11882664]

43. Nieminen J, St-Pierre C, Sato S. Galectin-3 interacts with naive and primed neutrophils, inducing innate immune responses. J Leukoc Biol. 2005; 78(5):1127-35. [PubMed: 16260586]

\section{Biographies}

Dr. Yuichi Uchino graduated from Keio University School of Medicine, Tokyo, Japan in 2001. Afterward, he worked as a resident in Department of Ophthalmology, Keio University School of Medicine, Tokyo, Japan. From 2012, he has been a postdoctoral research fellow at the Schepens Eye Research Institute, Harvard Medical School, Boston, Massachusetts. Dr. Uchino's primary research interests are the etiology of dry eye disease and the mechanism of glycocalyx barrier function.

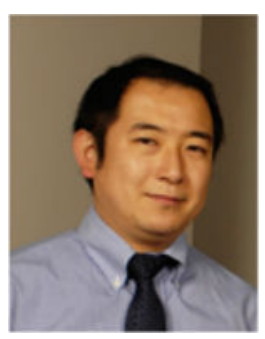

Dr. Pablo Argüeso received his Ph.D. (Biochemistry) in Spain in 1997. He is currently an Associate Professor of Ophthalmology at Harvard Medical School, and Associate Scientist at The Schepens Eye Research Institute/Massachusetts Eye and Ear. His research focuses on one of the last frontiers of molecular biology—glycobiology—analyzing the sugars that coat the surface of the eye and deciphering their role in protecting the eye against dehydration and pathogen invasion.

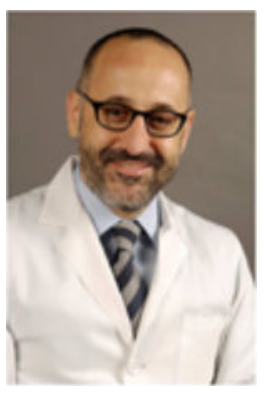




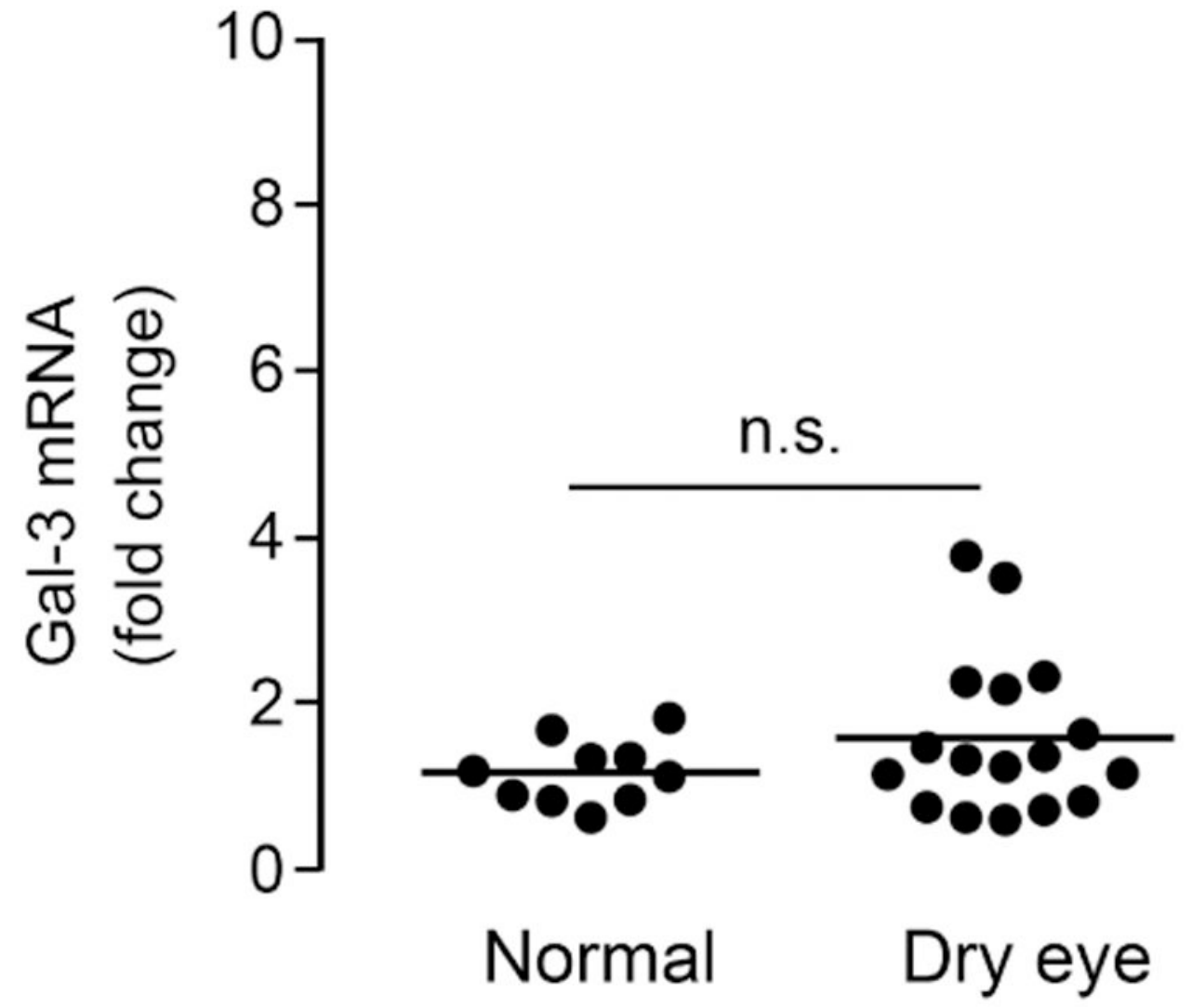




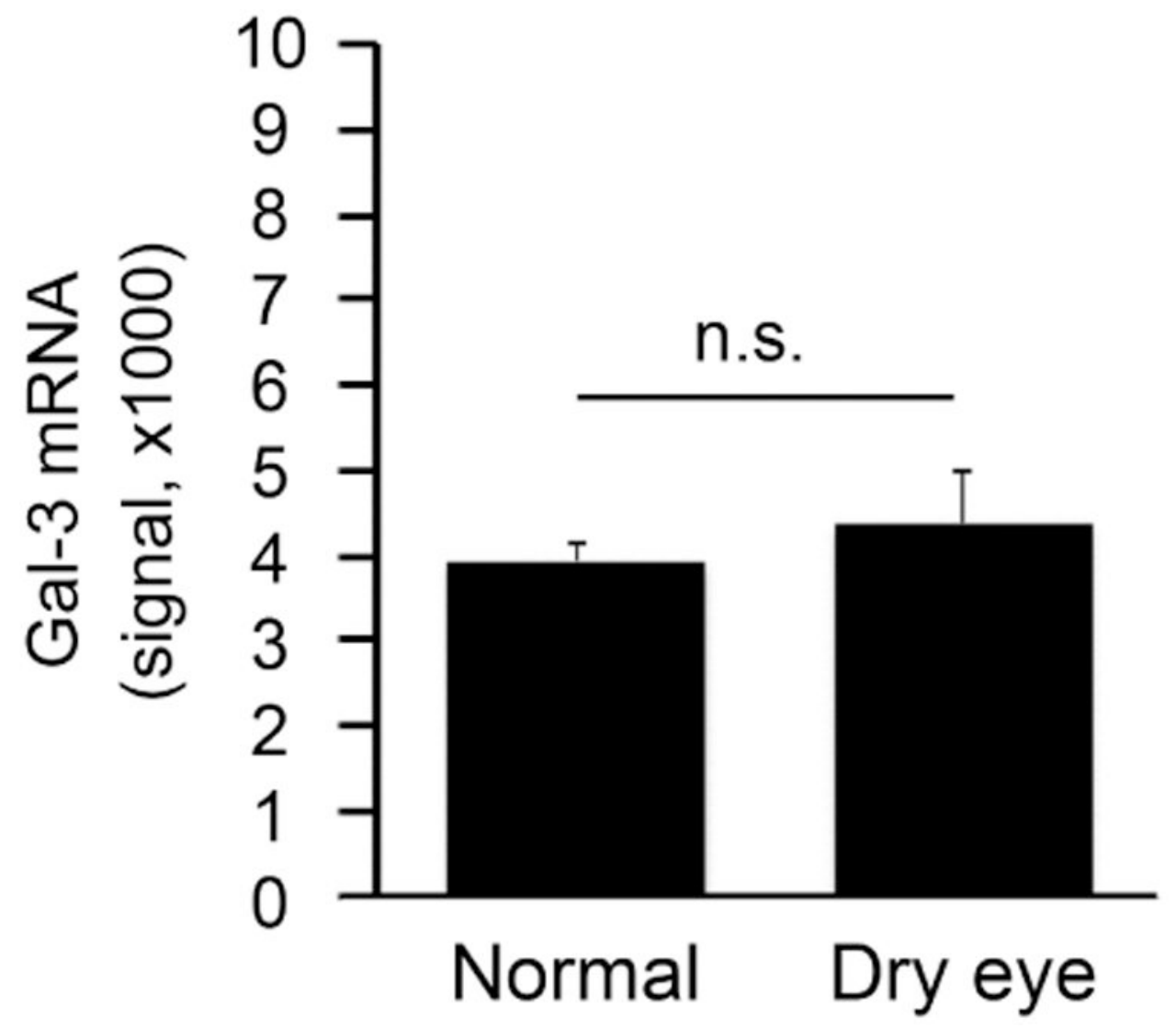

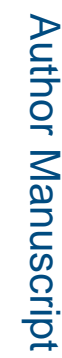

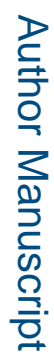


(kD)
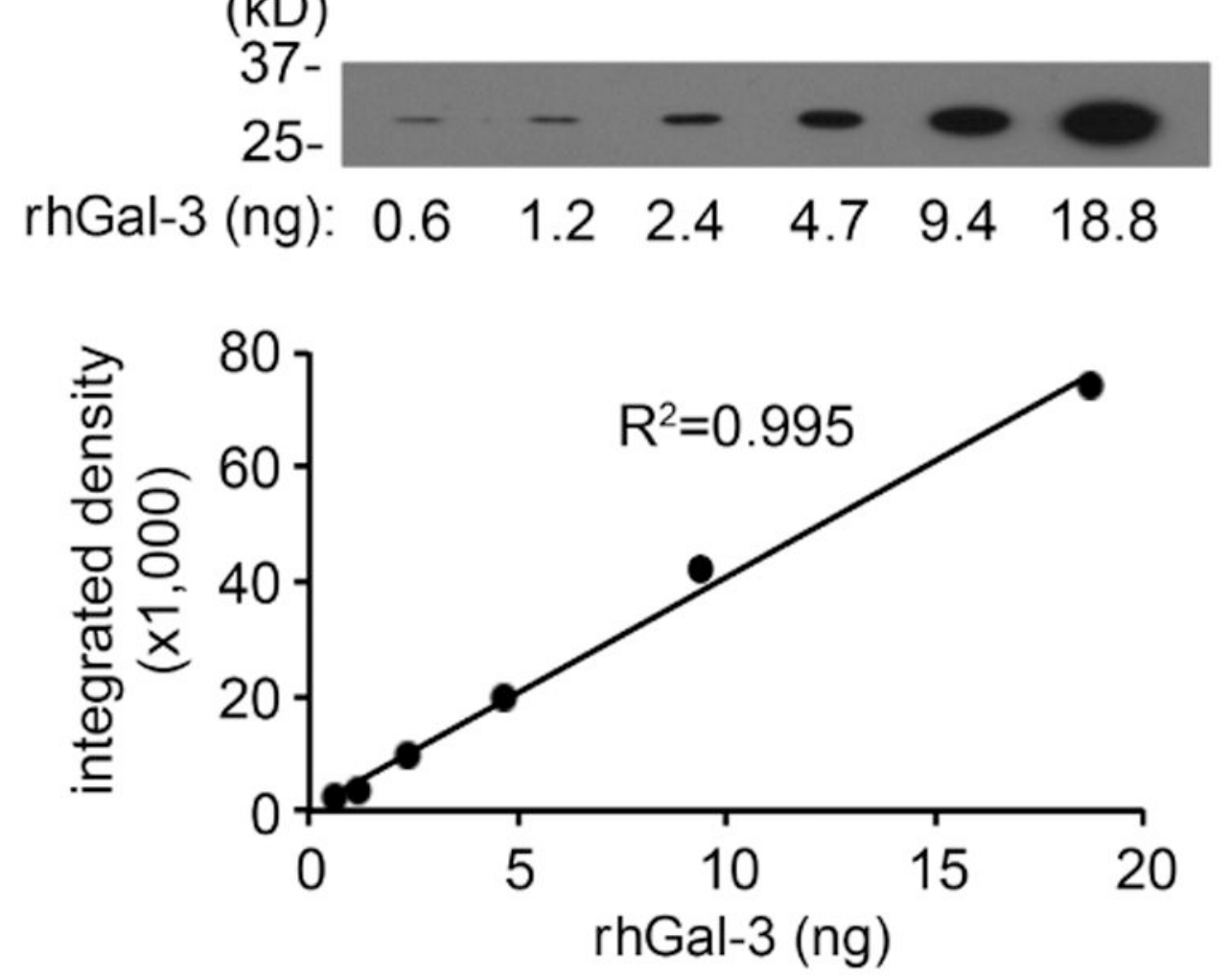

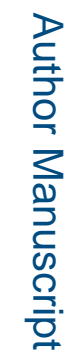

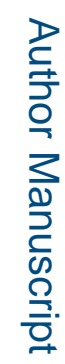




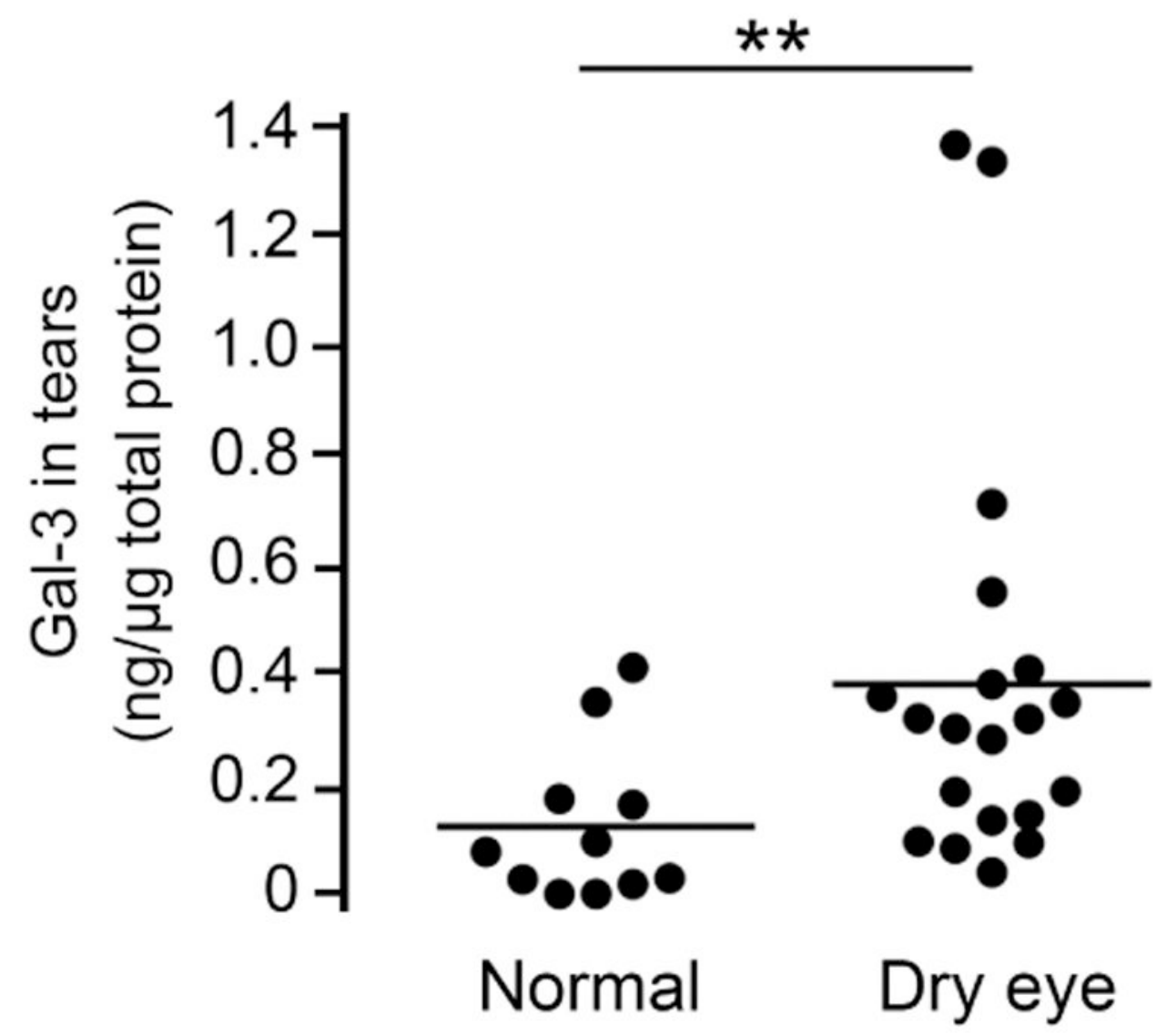

Figure 1.

Galectin-3 levels increase in tears of dry eye patients. (Upper left) Standard curve from a two-fold serial dilution series of recombinant human galectin-3 (rhGal-3). (Upper right) Quantification of galectin-3 concentrations in tear fluid from 11 normal subjects (11 eyes) and 16 dry eye patients ( 20 eyes) by immunoblotting. The relative intensities of endogenous galectin-3 in human tears were normalized to the amount of total protein. Data for individual samples are presented, with mean value indicated by horizontal bar for each group. (Lower left) Quantification of galectin-3 mRNA in conjunctival impression cytology samples from 10 normal subjects (10 eyes) and 15 dry eye patients (17 eyes) by qPCR. Data for individual samples are presented, with mean value indicated by horizontal bar for each group. (Lower right) Microarray analysis of impression cytology samples showing galectin-3 mRNA levels in human conjunctiva of normal and dry eye patients. Detailed data on glycogene expression can be found at http://www.functionalglycomics.org/glycomics/publicdata/microarray.jsp; Accession \# MAEXP_272_042605. **P <.01; n.s., not significant. Error bars indicate the standard deviation. 

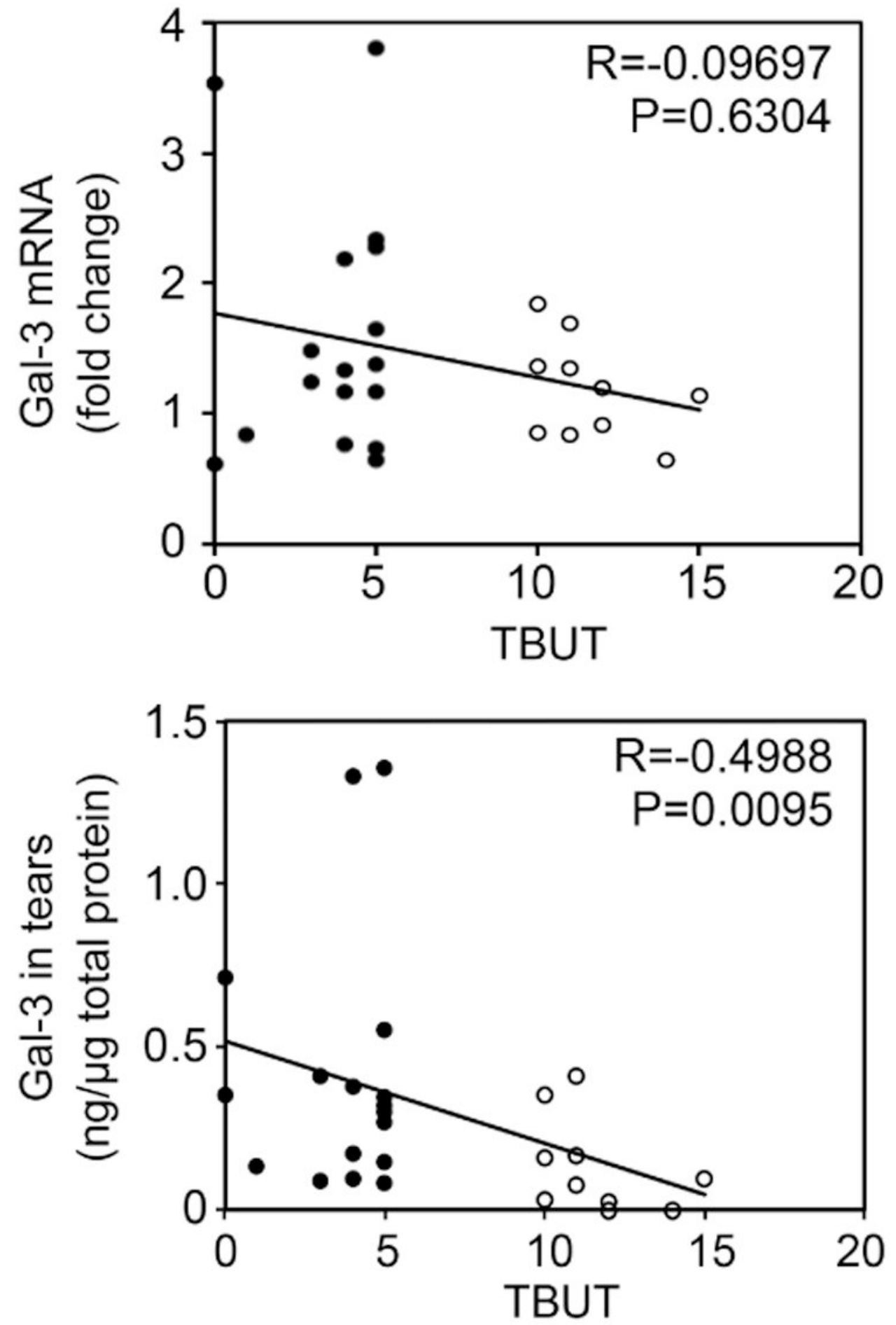

Figure 2.

Galectin-3 release into tears correlates with tear film instability. Scattergrams illustrating the correlations between the levels of galectin-3 in tears (upper panel) or galectin-3 mRNA (lower panel) from the same individuals and TBUT using the Spearman rank correlation test. Significance was achieved when correlating galectin-3 in tears $(\mathrm{R}=-0.4988 ; \mathrm{P}<.01)$, 
but not galectin-3 mRNA ( $R=-0.09697, P=0.6304)$, with TBUT. Black plots, dry eye patients; white plots, normal subjects. 


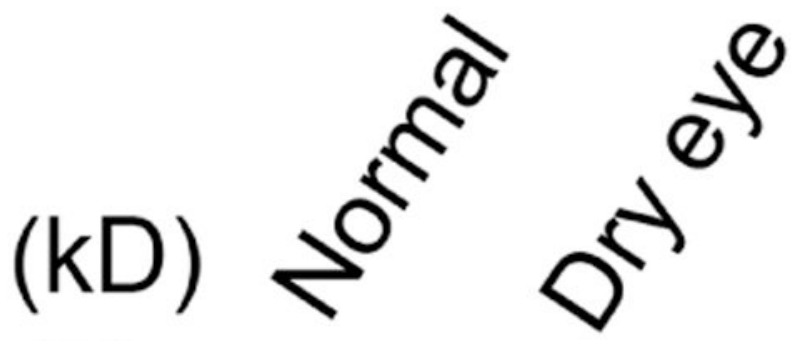

$50-$

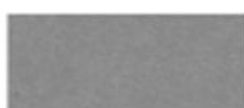

$37-$
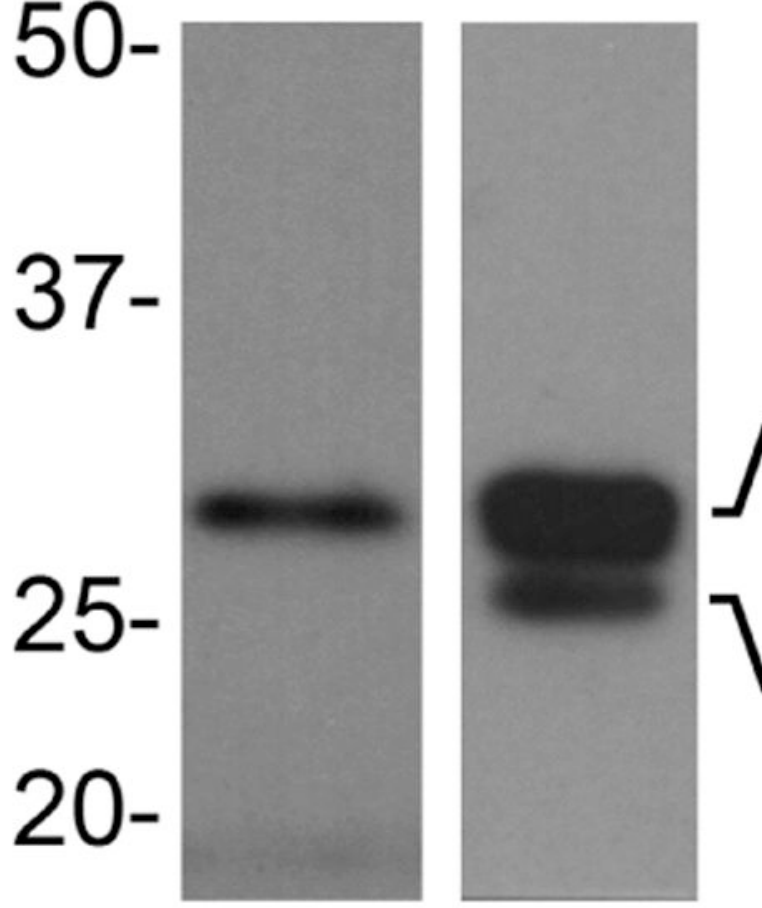

Gal-3

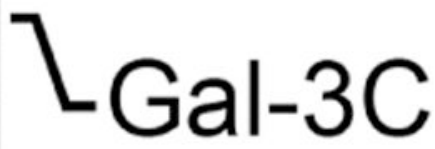

Galectin-3

( 30kD)

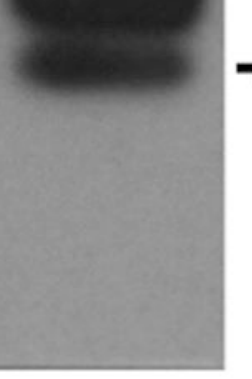

Multimerization Carbohydre-binding domain domain

Galectin-3C ( 22kD)

aa 63

250 


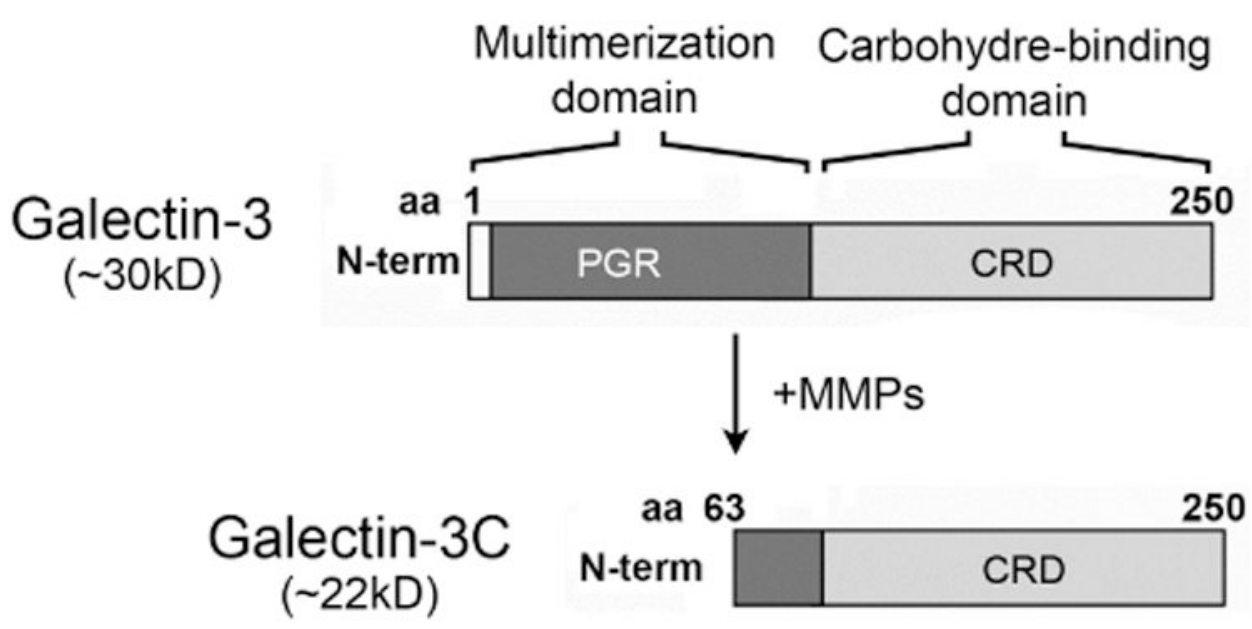

Figure 3.

Galectin-3 is partially degraded in tears of dry eye patients. (Upper panel) Schematic diagram illustrating the MMP-mediated cleavage of galectin- 3 at the $\mathrm{Ala}_{62}-\mathrm{Tyr}_{63}$ bond in the $\mathrm{N}$-terminus to produce a $22 \mathrm{kDa}$ cleavage product lacking the multimerization domain (galectin-3C). (Lower left) By immunoblot, a partially degraded form of galectin-3 with a molecular weight of $25.4 \mathrm{kDa}$ is detected in tears of patients with dry eye. (Lower right) Densitometric analyses revealed a significant increase in the ratio between galectin-3C and galectin-3 in tears of dry eye patients compared to tears of healthy subjects. Data for individual samples are presented. PGR, proline, glycine, and tyrosine-rich domain; CRD, carbohydrate recognition domain; N-term, N-terminus; aa, amino acid. $* \mathrm{P}<.05$. 

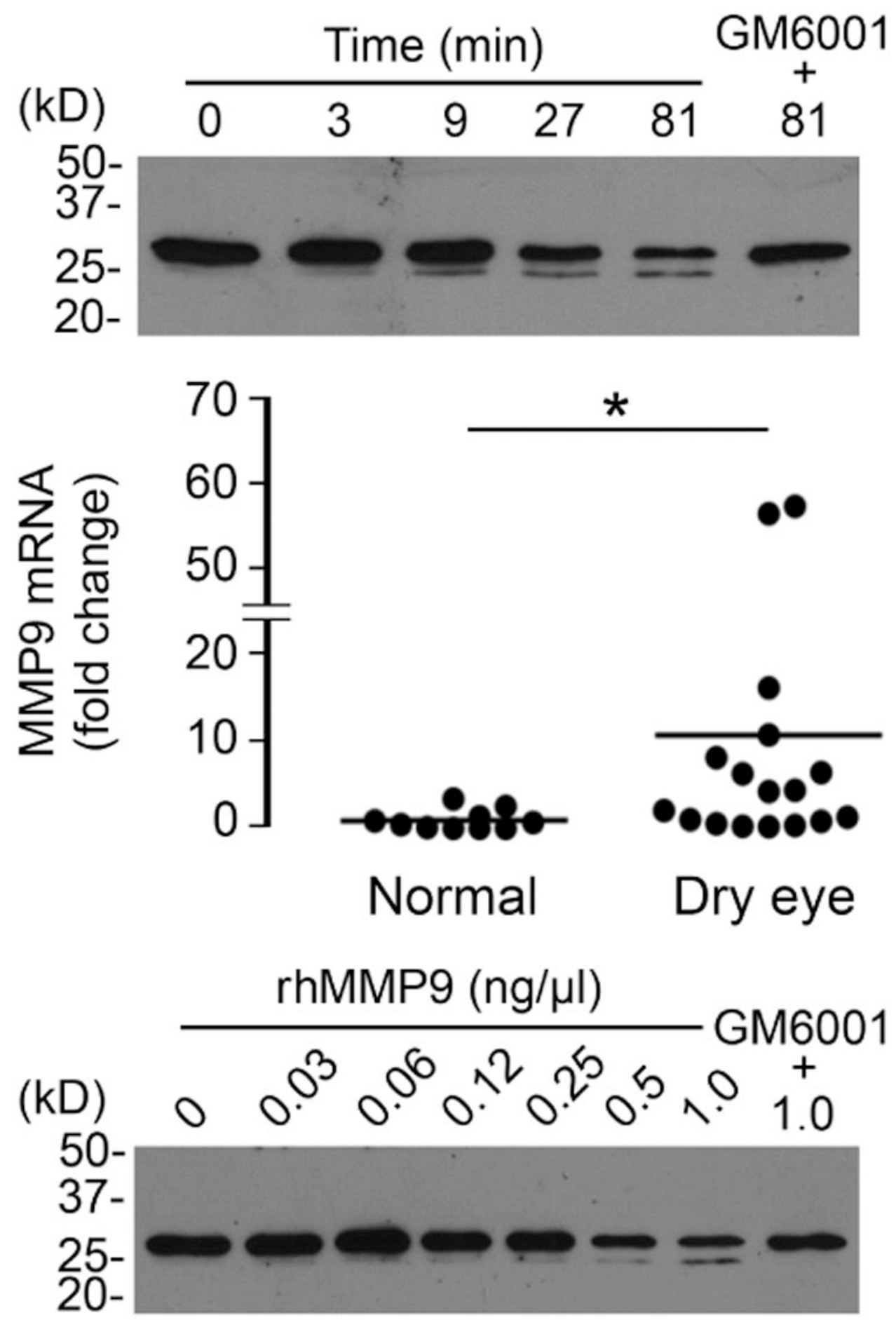

Figure 4.

Matrix metalloproteinase 9 promotes galectin-3 cleavage in vitro. (Upper panel)

Quantification of MMP9 mRNA in conjunctival impression cytology samples from 10 normal subjects ( 10 eyes) and 15 dry eye patients (17 eyes) by qPCR. Data for individual samples are presented, with mean value indicated by horizontal bar for each group. rhMMP9 promoted galectin-3 cleavage in a concentration- and time-dependent manner (middle and 
lower panels, respectively), producing a $25-\mathrm{kDa}$ cleavage product. Samples in the middle panel were incubated at $37{ }^{\circ} \mathrm{C}$ for $81 \mathrm{~min}$. Samples in the lower panel were incubated at 37 ${ }^{\circ} \mathrm{C}$ with $1.0 \mathrm{ng} / \mu \mathrm{l}$ rhMMP9. $* \mathrm{P}<.05$. 

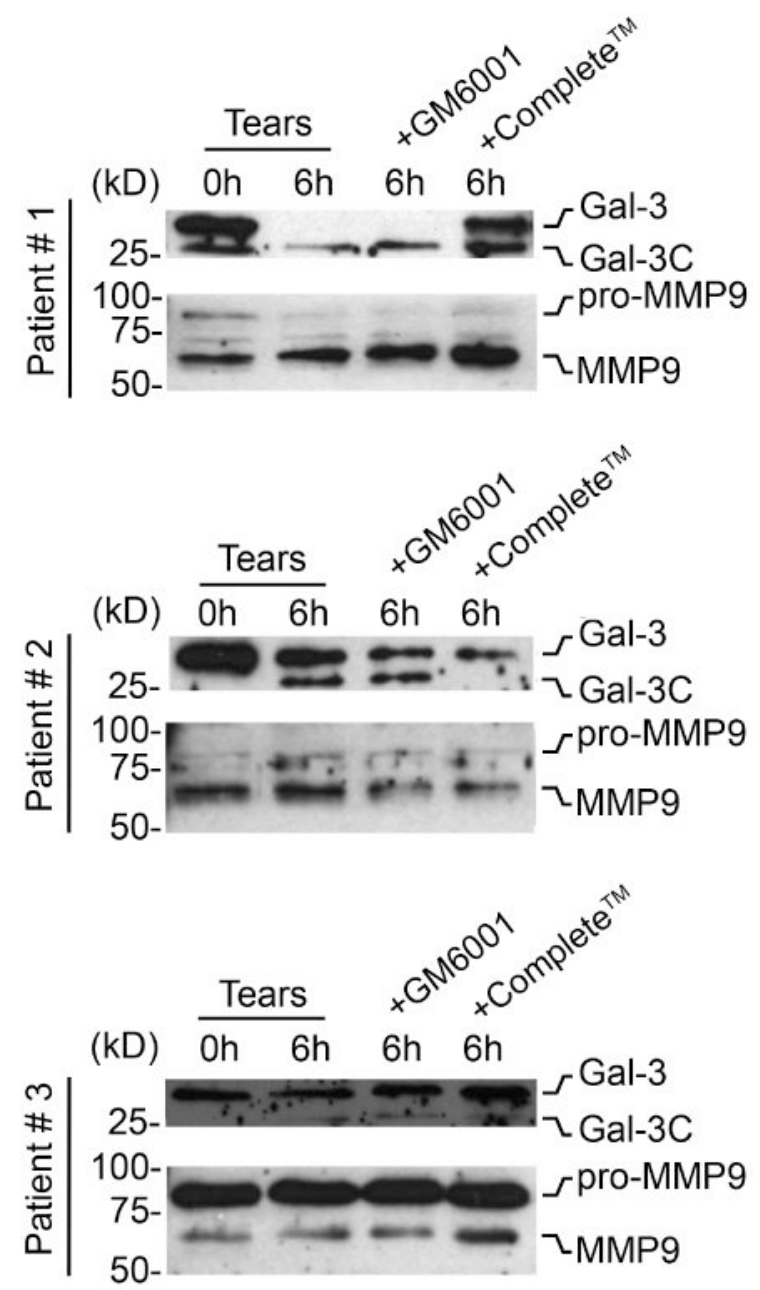

\section{Figure 5.}

Degradation of galectin-3 in human tears involves protease activity. Immunoblots demonstrating partial or complete degradation of endogenous galectin-3 in an in vitro assay using tears from three patients with dry eye. The broad-spectrum proteinase inhibitor cocktail complete $^{\mathrm{TM}}$, but not the pan-specific MMP inhibitor GM6001, impaired cleavage of galectin-3 in samples from two patients. The presence of the latent (pro-MMP9) and active forms of MMP9 in these tear samples was confirmed by immunoblot. MMP9 blots were from the same tear samples used in the galectin-3 blots above. 